\title{
RESTRUKTURISASI UTANG TERHADAP PERUSAHAAN GO PUBLIC DALAM KEPAILITAN DAN PKPU
}

\author{
F. Yudhi Priyo Amboro \\ Fakultas Hukum Universitas Internasional Batam \\ Jl. Gajah Mada, Baloi Permai, Batam 29442 \\ yudhi.amboro@gmail.com
}

\begin{abstract}
The compositions are still far away to be achieved in bankruptcy law. Eventhough the composition is the main key for the companies to survive, including for the go public companies. The purposes of this research are to get the description of the implementation in the debt restructuring of the go public companies in the process of bankruptcy and suspenment of payment, which was obtained from the compositions that were succeedly achieved. This research is an empirical juridical research. The approach is qualitative approach which was analyzed by deductive method. The results of this research is the implementation in debt restructuring of Go Public Company based on Bankruptcy Law of Indonesia is rescheduling and it becomes the common use, and combined with the other debt restructuring model.
\end{abstract}

Keywords: Debt Restructuring; Bankruptcy Law of Indonesia; Go Public Company

\begin{abstract}
Abstrak
Pencapaian perdamaian masih jauh dari harapan dalam hukum kepailitan. Meskipun perdamaian adalah kunci bagi perusahaan untuk tetap berlangsung, termasuk untuk perusahaan go public. Tujuan dari penelitian ini adalah untuk mendapatkan gambaran implementasi restrukturisasi utang perusahaan go public dalam proses kepailitan dan Penundaan Kewajiban Pembayaran Utang, yang dicapai dengan jalan perdamaian. Penelitian ini adalah penelitian yuridis empiris. Pendekatan yang digunakan adalah pendekatan kualitatif yang dianalisis dengan metode deduktif. Hasil penelitian adalah implementasi restrukturisasi utang perusahaan go public berdasarkan Hukum Kepailitan Indonesia adalah penjadwalan kembali pembayaran utang dan hal ini banyak digunakan dalam praktiknya dan dikombinasikan dengan model restrukturisasi utang yang lain.
\end{abstract}

Kata Kunci: Restrukturisasi Utang; Hukum Kepailitan Indonesia; Perusahaan Go Public

\section{A. Pendahuluan}

Akibat penjajahan di Indonesia yang didominasi oleh Belanda, maka kecenderungan tradisi hukum yang mengakar di Indonesia adalah Hukum Belanda. Maksud dari tradisi hukum di sini adalah sekumpulan sikap yang telah mengakar kuat dan terkondisikan secara historis terhadap hakikat hukum, aturan hukum dalam masyarakat dan ideologi politik, organisasi serta penyelenggaraan sistem hukum (De Cruz, 2010). Tradisi hukum dari Hukum Belanda tersebut kemudian dilanjutkan oleh Pemerintah Republik Indonesia yang berdaulat pasca kemerdekaan Indonesia untuk selanjutnya menjadi bagian dari hukum yang ada di wilayah Republik Indonesia.

Salah satu produk hukum yang masih menggunakan produk hukum Belanda di Indonesia adalah Hukum Kepailitan Indonesia, yang diwujudkan dalam Staatsblad 1905 No. 217 jo. Staatsblad 1906 
No. 348. Sejak dibentuknya negara Indonesia, Hukum Kepailitan yang tertuang dalam kedua Staatsblad tersebut berada dalam suatu tatanan Sistem Hukum Indonesia. Kemudian terjadi perubahan hukum oleh karena perekonomian Indonesia dalam keadaan terpuruk di tahun 1998. Selanjutnya digantikan dengan Peraturan Pemerintah Pengganti Undang-Undang Nomor 1 Tahun 1998 dan selanjutnya setelah diundangkan menjadi UndangUndang Nomor 4 Tahun 1998.

Secara empiris, implementasi UndangUndang Nomor 4 Tahun 1998 mengarahkan kreditor untuk mudah menyelesaikan permasalahan utang piutang di Pengadilan Niaga. Menurut Widjaja (2003), di tahun 1998 terdapat 31 permohonan pailit yang dibuat oleh kreditor, tahun 1999 terdapat 100 permohonan pailit, dan di tahun 2000 terdapat 84 permohonan. Sumber lain menyebutkan bahwa di tahun 2001 terdapat 61 permohonan pailit, di tahun 2002 terdapat 39 permohonan pailit, di tahun 2003 terdapat 38 permohonan pailit di Pengadilan Niaga pada Pengadilan Negeri Jakarta Pusat (Widjaja, 2003). Menurut Theresia Endang Ratnawati (2009), di tahun 1998 dan 1999 tidak terdapat permohonan Penundaan Kewajiban Pembayaran utang atau PKPU yang diajukan, di tahun 1999 terdapat 5 permohonan PKPU, di tahun 2000 terdapat 6 permohonan PKPU, di tahun 2001 terdapat 7 permohonan PKPU, dan di tahun 2002 terdapat 5 permohonan PKPU (Ratnawati, 2009). Di Pengadilan Niaga Jakarta Pusat, perdamaian yang dicapai melalui kepailitan di tahun 1998 ada 2 perkara, di tahun 1999 ada 5 perkara, di tahun 2000 ada 9 perkara, di tahun 2001 tidak ada, dan di tahun 2002 ada 8 perkara. Perdamaian yang dicapai melalui PKPU di tahun 1998 dan 1999 tidak ada, di tahun 2000 ada 4 perkara, di tahun 2001 ada 3 perkara dan di tahun 2002 ada 4 perkara. Perkara-perkara di atas menunjukkan adanya kebangkitan kesadaran penggunaan kepailitan dan PKPU sebagai lembaga penyelesaian permasalahan utang piutang yang memang pada waktu itu sangat dibutuhkan.

Selanjutnya pembuat hukum mengubah beberapa ketentuan dalam Hukum Kepailitan Indonesia, yang diwujudkan dalam Undang-Undang Nomor 37 Tahun 2004. Pasca berlakunya undang-undang tersebut, di tahun 2004 terdapat 52 permohonan pailit, di tahun 2005 terdapat 44 permohonan pailit, di tahun 2006 terdapat 59 permohonan pailit, di tahun 2007 terdapat 64 permohonan pailit dan bulan Januari sampai dengan April tahun 2009 terdapat 59 permohonan pailit di Pengadilan Niaga pada Pengadilan Negeri Jakarta Pusat. Secara keseluruhan, baik perkara kepailitan maupun PKPU, fakta menunjukkan bahwa dari 600 perkara kepailitan dan PKPU yang masuk ke Pengadilan Niaga di seluruh Indonesia, hanya 92 perkara atau sekitar $15 \%$ yang diselesaikan dengan perdamaian, sedangkan 297 perkara atau sekitar 49\% debitor dinyatakan pailit dan dilikuidasi (Sitompul, 2009).

Fakta-fakta di atas menunjukkan bahwa pencapaian perdamaian dalam proses kepailitan dan PKPU di Indonesia masih sangat sedikit. Padahal Undang-Undang Nomor 37 Tahun 2004 sudah memberikan fasilitas penyelesaian berupa perdamaian, baik di dalam proses kepailitan maupun di dalam proses PKPU. Perdamaian tidak didefinisikan oleh Undang-Undang Nomor 37 Tahun 2004, akan tetapi pemahaman secara umum dapat merujuk pada pandangan Pasal 222 Undang-Undang Nomor 37 Tahun 2004 yang pada prinsipnya rencana perdamaian meliputi tawaran pembayaran sebagian atau seluruh utang kepada kreditor. Menurut Sutan Remy Sjahdeini (2002), tawaran seperti itu terkategori bentuk restrukturisasi utang (Sjahdeini, 2002).

Perseroan Terbatas Go Public yang melalui proses kepailitan maupun PKPU diharuskan melalui tahapan yang telah ditentukan oleh Undang-Undang No. 37 Tahun 2004, tahapan yang tidak berbeda dengan jenis perseroan terbatas tertutup. 
Tahapan yang dilalui berdasarkan ketentuan undang-undang adalah tahapan yang efektif dengan adanya pembatasan waktu untuk penyelesaiannya, termasuk dari awal proses persidangan yang diawali dengan adanya permohonan, sampai pada tahapan pemberesan boedel pailit, jika itu adalah proses pailit, dan tahapan pengesahan perdamaian dalam PKPU, jika itu adalah proses PKPU. Salah satu tahapan yang penting dan menentukan di dalam Kepailitan dan PKPU adalah tahapan ketika debitor diminta untuk menyampaikan rencana perdamaian yang berisi mengenai cara-cara debitor untuk melakukan pembayaran utangnya kepada para kreditor menurut Pasal 144 dan Pasal 265 Undang-Undang No. 37 Tahun 2004. Di sinilah posisi restrukturisasi utang dijalankan terhadap perusahaan yang telah dinyatakan pailit maupun dinyatakan dalam PKPU Sementara ataupun PKPU Tetap.

Berdasarkan hal-hal di atas, penelitian ini fokus pada rumusan masalah "bagaimana implementasi restrukturisasi utang terhadap Perusahaan Go Public dan permasalahan yang muncul berdasarkan Hukum Kepailitan Indonesia?". Rumusan masalah tersebut diangkat untuk dapat mencapai tujuan penelitian yaitu mendapatkan gambaran mengenai implementasi restrukturisasi utang terhadap perusahaan go public dan segala permasalahan yang muncul. Hasil penelitian ini dapat digunakan untuk merumuskan restrukturisasi utang dalam perdamaian yang bagaimana yang berpeluang disetujui oleh kreditor.

\section{B. Metode Penelitian}

Penelitian ini adalah penelitian yuridis empiris. Harapan dari penelitian yuridis empiris ini adalah dapat mengungkap dan mengurai segala tahapan yang terjadi dalam tataran empiris mengenai restrukturisasi utang yang terjadi dalam proses kepailitan dan PKPU terhadap perseroan terbatas go public. Data primer didapatkan dengan melakukan studi lapangan dalam bentuk observasi dan wawancara. Observasi yang digunakan adalah participant observation dan non participant observation. Cara wawancara yang digunakan adalah wawancara secara mendalam atau indepth interview kepada narasumber yang telah dipilih, dengan menggunakan metode purposive sampling. Data sekunder didapatkan dengan cara studi kepustakaan, dimana dilakukannya penelusuran literatur sesuai dengan bahan hukum yang terkait dengan obyek penelitian ini. Data yang telah diperoleh tersebut di atas kemudian diproses dengan pendekatan kualitatif yang didukung dengan analisis dengan menggunakan cara pikir deduktif. Tahapan awal yang dilakukan dalam melakukan analisis deskriptif terkait perkara-perkara kepailitan dan PKPU terhadap perseroan terbatas go public, lalu dipilah-pilah sesuai dengan tujuan penelitian ini, yaitu menemukan restrukturisasi utang yang ada di dalam perkara-perkara tersebut. Segala fakta yang muncul terkait dengan proses pembentukan restrukturisasi utang selanjutnya dianalisis untuk mencapai tujuan penelitian ini.

\section{Hasil dan Pembahasan}

\section{Perkara Kepailitan dan PKPU Terhadap Perusahaan Go Public}

Sejak awal rezim Undang-Undang No. 4 Tahun 1998, di tahun 1998 sampai dengan tahun 2004 dan rezim Undang-Undang No. 37 Tahun 2004, sejak tahun 2004 sampai dengan tahun 2017, yang terkait dengan Perusahaan Go Public sebagai debitornya menurut hasil penelusuran penelitian ini terdapat 21 perkara kepailitan dan 15 perkara PKPU. Hampir keseluruhan perkara yang terkait dengan Perusahaan Go Public sebagai debitor, baik kepailitan maupun PKPU, berada di Pengadilan Niaga pada Pengadilan Negeri Jakarta Pusat, meskipun demikian terdapat 2 perkara PKPU yang berada di Pengadilan Niaga pada Pengadilan Negeri Surabaya.

Dalam penelusuran penelitian ini, debitor dalam perkara PKPU yang berhasil mencapai adanya perdamaian dengan para kreditornya adalah perkara PKPU PT. Davo 
Abadi Tbk, perkara PKPU PT. Arpeni Pratama Ocean Line Tbk, perkara PKPU PT. Berlian Laju Tanker Tbk, perkara PKPU PT. Trikomsel Oke Tbk, perkara PKPU PT. Dwi Aneka Jaya Kemasindo Tbk, dan perkara PKPU PT. Bumi Resources Tbk. Penelitian ini tidak menemukan adanya perkara kepailitan yang berhasil mencapai perdamaian dalam prosesnya dalam kaitan dengan Perusahaan Go Public. Debitor dalam perkara PKPU yang tidak berhasil mencapai perdamaian dengan para kreditornya adalah perkara PKPU PT. Texmaco Jaya Tbk, perkara PKPU PT. Dayaindo Resources International Tbk dan perkara PKPU PT. Daya Mandiri Resources Indonesia Tbk, dan perkara PKPU PT. Citra Maharlika Nusantara Corpora Tbk, yang kesemuanya berujung pada proses kepailitan.

Latar belakang permasalahan ketiga perusahaan yang berhasil melakukan perdamaian dengan kreditornya berbeda satu dengan yang lain. Utang yang timbul adalah utang sebagai penjamin obligasi anak perusahaannya, seperti PT. Davomas Abadi Tbk. Ada juga utang yang timbul yang langsung kaitannya dengan bisnis perusahaan, seperti PT. Trikomsel Oke Tbk. Kunci keberhasilan PT. Arpeni Pratama Ocean Tbk, PT. Davomas Abadi Tbk dan PT. Trikomsel Oke Tbk mencapai perdamaian dengan kreditornya adalah perusahaan tersebut aktif melakukan pendekatan dengan para kreditornya, sehingga para kreditor masing-masing perusahaan tersebut yakin dengan rencana restrukturisasi utang yang diajukan. Misalnya PT. Arpeni Pratama Ocean Tbk yang berhasil mencapai perdamaian dalam waktu kurang lebih 1 bulan setelah perusahaan tersebut mendapatkan PKPU Tetap. PT. Davomas Abadi Tbk yang aktif melakukan pendekatan dengan kreditornya sebelum terjadinya PKPU, sehingga ketika terjadi pembahasan dalam proses PKPU perdamaian lebih cepat dicapai. PT. Trikomsel Oke Tbk aktif menyusun rencana restrukturisasi utang yang sangat baik dan detail dalam proses PKPU, dibandingkan dengan rencana restrukturisasi utang yang disusun oleh PT. Arpeni Pratama Ocean Tbk, sehingga PT. Trikomsel Oke Tbk dapat meyakinkan kreditornya. Keyakinan para kreditor untuk menyetujui rencana perdamaian yang berisi restrukturisasi utang tidak hanya terletak pada posisi debitor yang aktif melakukan pendekatan saja, tetapi juga rencana perdamaian tersebut terkategori layak atau visible, ditinjau dari kajian solvabilitas dari debitor. Meskipun rencana perdamaian yang dibuat itu sangat bagus dan detail, akan tetapi kreditor akan melihat solvabilitas debitor untuk mengukur seberapa mampu debitor membayar utangnya. Oleh karena itu, terhadap perdamaian yang telah disetujui, nantinya akan diuji lagi apakah solvable atau tidak pada waktu perdamaian tersebut dilaksanakan. Apabila tidak solvable akan berakibat pada perbuatan wanprestasi debitor, sehingga mengakibatkan kreditor yang dirugikan dapat mengajukan pembatalan perdamaian. Pada akhirnya debitor tersebut akan menjadi pailit dan dilikuidasi hartanya.

\section{Restrukturisasi Utang Terhadap Perusahaan Go Public Dalam Proses Kepailitan dan PKPU}

Rencana perdamaian di proses kepailitan maupun PKPU merupakan rancangan restrukturisasi utang. Melihat hasil penelusuran perkara di atas, baik perkara kepailitan maupun PKPU mempunyai kesempatan untuk menyampaikan rencana perdamaian yang nantinya akan dapat menjadi bagian dari restrukturisasi utang, meskipun terdapat penolakan kreditor rencana perdamaian yang diajukan oleh debitor. Undang-Undang ini dibentuk untuk memberikan kesempatan yang luas bagi debitor untuk lepas dari jeratjerat utang dan diberikan perlindungan oleh hukum sebagaimana mestinya, terutama bagi debitor beritikad baik yang masih mempunyai potensi kelangsungan usaha. Di dalam kepailitan, hal tersebut diatur di dalam Pasal 144 Undang-Undang No. 37 Tahun 2004. Dalam menanggapi rencana 
perdamaian yang diajukan oleh debitor pailit dalam kepailitan, ada kewajiban yang muncul kepada kurator dan panitia kreditor sementara untuk memberikan pendapat tertulisnya terkait dengan rencana perdamaian tersebut. Hal ini di dalam praktik jarang sekali dilakukan, meskipun diwajibkan oleh Pasal 146 Undang-Undang No. 37 Tahun 2004 sekalipun, halmana didapatkan dari hasil wawancara dengan kurator dan pengurus serta hasil observasi. Hal yang paling sering dilakukan di dalam praktik adalah setelah rencana perdamaian dalam kepailitan dilakukan oleh debitor pailit, selanjutnya akan dilemparkan kepada forum dalam rapat kreditor yang sebelumnya diberikan kesempatan bagi para kreditor untuk mempelajarinya terlebih dahulu. Menurut kurator yang diwawancarai, kebanyakan debitor yang menghadapi kepailitan mengajukan rencana perdamaian pada waktu diselenggarakannya rapat kreditor, dan bukan sebelum rapat kreditor yang mengagendakan pencocokan piutang. Hal ini menyebabkan kurator tidak mempunyai waktu lagi untuk melakukan tanggapan tertulis terkait dengan rencana perdamaian, karena setelah agenda pencocokan piutang selesai, selanjutnya adalah membahas mengenai rencana perdamaian.

Di dalam PKPU, ketentuan rencana perdamaian diatur di dalam Pasal 265 Undang-Undang No. 37 Tahun 2004. Berbeda dengan rencana perdamaian dalam konsep kepailitan yang merupakan jalan alternatif untuk supaya menghindarkan insolvensi dan pemberesan harta pailit, di dalam PKPU justru tujuan utamanya adalah supaya tercapai perdamaian dan oleh karenanya hukum memberikan penundaan untuk debitor melakukan pembayaran utang dan untuk kreditor melakukan penagihan piutang. Hal ini nampak di dalam Pasal 222 ayat (2) dan ayat (3) Undang-Undang No. 37 Tahun 2004. Rencana perdamaian dalam PKPU yang telah disampaikan kemudian juga diberikan kewajiban oleh hukum untuk ditanggapi ataupun diberikan pendapat secara tertulis oleh pengurus maupun ahli apabila diangkat. Hal ini merupakan kewajiban yang muncul berdasarkan ketentuan Pasal 278 ayat (1) UndangUndang No. 37 Tahun 2004. Sama halnya dengan pemberian pendapat secara tertulis atas rencana perdamaian oleh kurator di dalam proses kepailitan, di dalam praktiknya pemberian pendapat tertulis dalam proses PKPU pun jarang sekali dilaksanakan. Justru langkah selanjutnya adalah menyampaikan rencana perdamaian tersebut kepada para kreditor supaya mendapatkan persetujuan atau penolakan. Alasan yang sama dilakukan dalam proses PKPU, menurut pengurus yang diwawancarai, debitor dalam menyampaikan rencana perdamaian biasanya dilakukan di waktu yang terlalu dekat dengan waktu rapat kreditor, sehingga membuat pengurus tidak mempunyai banyak waktu untuk menanggapi rencana perdamaian dari debitor, dan selanjutnya pengurus menyampaikan kepada rapat kreditor untuk dibahas di dalam forum sekaligus menentukan apakah PKPU dilanjutkan menjadi PKPU tetap, jika masih berada pada tahap PKPU Sementara, dan menentukan apakah ada perpanjangan waktu PKPU, jika berada pada tahap PKPU tetap.

Di dalam penelusuran penelitian ini, terkait dengan perkara-perkara kepailitan dan PKPU yang terkait dengan Perusahaan Go Public, ternyata tidak ditemukan adanya rencana perdamaian yang disetujui oleh para kreditornya di dalam proses kepailitan, tetapi lebih banyak rencana perdamaian disetujui oleh para kreditornya di dalam proses PKPU. Menurut Hakim Pengawas yang diwawancarai, kreditor dalam perkara yang melibatkan Perusahaan Go Public, kebanyakan mempunyai kemampuan untuk menilai tingkat solvabilitas debitor. Ketika kreditor tidak dapat diyakinkan dengan kondisi solvabilitas debitornya atau kondisi lain yang dapat memberikan kepastian bagi kreditor, maka kreditor lebih cenderung memilih likuidasi. Hal ini juga dibenarkan oleh kurator yang diwawancarai, yang menurut kurator ada kreditor yang sejak awal sudah mengetahui bahwa debitornya 
dalam kondisi insolven, dan oleh karenanya patut untuk dilikuidasi daripada diselamatkan perusahaannya. Perkara PT. Arpeni Pratama Ocean Line Tbk merupakan salah satu contoh keberhasilan pencapaian perdamaian di dalam PKPU, meskipun dalam perjalanan waktunya terjadi hambatan yang harus dihadapi oleh perusahaan ini. Perkara PT. Trikomsel Oke Tbk juga merupakan salah satu contoh keberhasilan pencapaian perdamaian di dalam PKPU. Untuk itu, perlu dilihat lagi mengenai detail rencana perdamaian yang ditawarkan dan disetujui oleh para kreditornya, baik kreditor konkuren maupun kreditor separatis.

Dalam penelusuran penelitian ini ditemukan fakta bahwa pembayaran sebagian atau seluruh utang kepada kreditor sesuai dengan konsep perdamaian, baik di dalam kepailitan maupun PKPU, bisa bersifat langsung maupun tidak langsung. Bersifat langsung, jika debitor di dalam rencana perdamaiannya menyatakan restrukturisasi utangnya. Bersifat tidak langsung, jika debitor di dalam rencana perdamaiannya menyatakan memanfaatkan bisnis perusahaannya secara optimal dan selanjutnya dapat melakukan pembayaran kepada kreditornya. Hal ini nampak di dalam perkara PT. Argo Pantes, Tbk. dalam perkara No. No. 03/PKPU/2006/PN.NIAGA.JKT.PST jo. No. 05/PAILIT/2006/PN.NIAGA.JKT.PST dimana debitor sebagai pemohon PKPU telah mengajukan rencana perdamaian berupa debt to equity swap yang mengkonversi utangnya menjadi bagian saham dari perusahaan tersebut. Hal ini merupakan bagian dari restrukturisasi perusahaan dan sekaligus pembayaran secara tidak langsung kepada kreditornya, minimal dalam bentuk dividen.

Bentuk restrukturisasi utang yang diajukan oleh debitor kepada kreditornya, baik di dalam kepailitan maupun di dalam PKPU, yang paling sering adalah rescheduling. Rescheduling adalah penjadwalan kembali berkaitan dengan waktu pembayaran berupa pelunasan utang pokok maupun bagi hasil, profit margin, maupun fee yang merupakan kewajiban dari debitor (Amalia, Thaif, Nasution, \& Sunarmi., 2013). Hal ini juga disampaikan oleh Hakim Pengawas yang diwawancarai, yang menyatakan bahwa rescheduling menjadi rencana favorit para debitor dalam proses di kepailitan dan PKPU. Rescheduling memberikan jadwal yang pasti terkait pengembalian dana kreditor, sehingga pemberian kepastian seperti ini lebih disukai kreditor. Restrukturisasi utang tersebut bisa dilaksanakan dalam waktu yang pendek maupun panjang, bahkan ada juga debitor yang mengajukan rencana perdamaian berupa rescheduling sampai dengan puluhan tahun. Kreditor di dalam praktiknya lebih suka menerima rencana perdamaian rescheduling dalam waktu yang pendek, antara 5-6 tahun paling lama, mengingat dalam waktu tersebut masih terjangkau bagi kreditor untuk menunggu. Apalagi bagi kreditor yang telah mengeluarkan segala modalnya untuk dapat berbisnis dengan debitor, yang pada akhirnya pembayarannya pun macet.

Perdamaian yang terjadi antara PT. Trikomsel Oke Tbk dengan kreditornya adalah salah satu contohnya adanya praktik rescheduling, tetapi dengan menggunakan kombinasi debt to equity swap, hair cut dan juga pengurangan dan penundaan jumlah bunga tertunggak. Hair cut merupakan pemotongan pokok pinjaman dan bunga (Irianto, 2015). Perkara PT. Dayaindo Resources International Tbk dan PT. Daya Mandiri Resources Tbk dalam perkara No. 46/Pailit/2012/PN.Niaga.Jkt.Pst juga menunjukkan adanya model rescheduling utang, yang dikombinasi dengan asset sales dan equity carve-outs serta penambahan utang baru, meskipun tidak disetujui oleh sebagian besar kreditornya. Asset sales terkadang menjadi pilihan karena menurut John \& Ofek (John \& Ofek, 1995), asset sales atau penjualan aset mengarah pada peningkatan kinerja operasional dari sisa aset perusahaan penjual dalam tiga tahun setelah penjualan aset. Peningkatan kinerja terjadi terutama pada perusahaan penjual yang fokus pada bisnis yang ditetapkan. 
Equity carve-outs juga menjadi pilihan karena adanya keuntungan abnormal ratarata muncul karena equity carve-out setelah pengumuman penawaran publik ekuitas induk (Schipper \& Smith, 1986). Menurut Apostolos Dasilas \& Stergios Leventis (2018), demikian equity carve-outs diumumkan akan menghasilkan pengembalian abnormal yang signifikan bagi pemegang saham perusahaan induk.

Permasalahan pengajuan rencana perdamaian kepada kreditor sebenarnya merupakan cerminan keberlangsungan usaha, dengan kata lain jika debitor mengajukan rencana perdamaian yang materinya dalam batas kewajaran kreditor, maka itu menandakan bahwa debitor masih going concern, yang berarti debitor masih dapat melanjutkan usahanya dengan baik. Going concern juga dapat dilihat dari sisi analisis solvabilitasnya. Menurut Kukuh Komandoko Hadiwidjojo (2016), analisis solvabilitas dilakukan dengan cara membandingkan keadaan total aset dengan total kewajiban. Suatu perusahaan dikatakan memiliki kondisi yang baik apabila perusahaan dapat memenuhi kewajibannya, baik kewajiban jangka pendek maupun kewajiban jangka panjang (Hadiwidjojo, 2016). Dalam hal ini, analisis terhadap solvabilitas dilakukan untuk memastikan apakah aset yang dimiliki oleh debitor mampu untuk mendukung seluruh kegiatan bisnisnya. Menurut narasumber dari Bursa Efek Indonesia yang diwawancara, Perusahaan Go Public yang tetap mempertahankan posisinya untuk tetap berada dalam daftar emiten di Bursa Efek Indonesia, biasanya adalah perusahaan yang ingin tetap melanjutkan usahanya secara optimal.

Kondisi di atas menunjukkan bahwa kepailitan maupun PKPU, bukan merupakan perkara yang bisa dianggap ringan oleh debitor, karena akibatnya tidak baik bagi kelangsungan usaha debitor. Sifat putusan pailit yang serta merta didasarkan atas ketentuan Pasal 16 Undang-Undang No. 37 Tahun 2004, mengakibatkan debitor berpotensi dirugikan hartanya oleh karena kurator yang secara hukum harus dominan melakukan pengurusan dan pemberesan harta debitor, termasuk kurator diperkenankan jika harus melakukan penjualan harta sebelum putusan hasil upaya hukum Kasasi maupun Peninjauan Kembali diterima. Kegagalan perdamaian di dalam proses PKPU, juga mengakibatkan harta debitor harus dilikuidasi, tanpa ada kesempatan lagi bagi debitor untuk mengajukan upaya hukum apapun. Hal ini berarti bahwa pencapaian kesepakatan dalam perdamaian yang berisi restrukturisasi utang, baik di dalam proses kepailitan maupun PKPU, yang akan lebih menguntungkan daripada proses dibiarkan berjalan terlalu lama sehingga akan menurunkan nilai harta debitor. Penurunan nilai harta debitor tersebut oleh karena sedikit demi sedikit harta debitor harus dijual untuk pembiayaan kepailitan maupun PKPU.

Dalam tataran implementasi restrukturisasi utangnya, ternyata menurut hasil wawancara dengan narasumber kurator kepailitan dan pengurus PKPU, debitor banyak melakukan modifikasi terhadap rescheduling, seperti menjual aset dari debitor sebagian, mencari ekuitas baru, atau dengan model lain yang selain rescheduling juga mengkonversi utang menjadi saham (debt to equity swap), sehingga kreditor yang bersedia dapat menjadi pemegang saham dari perusahaan debitor. Selain contoh di dalam perkara PT. Trikomsel Oke Tbk di atas, model rencana perdamaian seperti itu pernah dilakukan dalam perkara No. 03/PKPU/2006/PN.Niaga,Jkt.Pst jo. No. 05/Pailit/2006/PN.Niaga.Jkt.Pst. Di dalam perkara tersebut PT. Argo Pantes Tbk awalnya dimohonkan pailit oleh Indo Plus $\mathrm{BV}$, terkait dengan utang yang telah jatuh tempo sebesar US\$ 12,000,000 (dua belas juta dollar Amerika Serikat), tetapi selanjutnya PT. Argo Pantes, Tbk melakukan counter dengan cara memohon PKPU. Di dalam PKPU-nya PT. Argo Pantes Tbk kemudian mengajukan rencana perdamaian dengan para kreditornya, 
dengan mengajukan debt to equity swap, dan disetujui oleh para kreditornya.

Penawaran debt to equity swap juga pernah dilakukan oleh PT. Sekar Laut, Tbk kepada para kreditornya melalui mekanisme PKPU di Pengadilan Niaga pada Pengadilan Negeri Surabaya dengan perkara No. 08/PKPU/2005/PN.Niaga.Sby, yang selanjutnya disetujui oleh para kreditornya. Debt to equity swap secara teori dapat dikategorikan sebagai bagian dari akuisisi atau pengambilalihan suatu perusahaan, dalam hal terjadi peralihan pengendalian atas perusahaan yang bersangkutan, mengingat ketentuan Pasal 125 ayat (1) Undang-Undang No. 40 Tahun 2007 menyatakan pada prinsipnya bahwa pengambilalihan dapat dilakukan atas saham yang akan dikeluarkan. Dalam debt to equity swap, setidaknya baik pemegang saham maupun perseroan terbatas akan mengeluarkan sejumlah saham di dalam saham portopel guna menggantikan kedudukan utang, dengan harapan nilai utang menjadi tidak ada lagi, atau setidaknya menjadi berkurang (Kairupan, 2014). Debt to equity swap menurut prinsip akuntansi mempunyai rasio di mana jika rasionya tinggi maka dapat memberikan pengembalian yang lebih tinggi kepada pemegang sahamnya (Sari \& Hutagaol, 2009). Selain itu, memilih debt to equity swap, akan menyebabkan perkuatan status kepemilikan perusahaan, dengan demikian akan meningkatkan kemampuan bersaing bagi debitor di kemudian hari (Respatia \& Fidiana, 2010).

Dalam praktiknya, menurut kurator dan pengurus yang diwawancarai, debitor yang mengajukan rencana perdamaian berupa rescheduling dalam jangka waktu yang pendek biasanya melakukan secara mandiri operasional perusahaannya tanpa bantuan pihak lain terutama kreditor. Tetapi jika rescheduling lebih dari 5 tahun, maka biasanya debitor dibantu oleh kreditornya, terutama kreditor dari bidang keuangan, yaitu perbankan. Dalam implementasinya, kreditor perbankan bersedia membantu debitor jika ia mempunyai itikad baik dan masih berpotensi going concern, dengan cara mengucurkan penambahan kredit ke debitor. Dari dana kredit ini nantinya debitor akan mengelolanya untuk menjalankan kegiatan usahanya, dengan pengawasan ketat dari kreditor.

Berdasarkan analisis di atas, pada prinsipnya Hukum Kepailitan Indonesia telah diuji dalam rangka pencapaian perdamaian yang berisi mengenai restrukturisasi utang, yang pada kenyataannya tidak tercapai secara maksimal, baik di dalam proses kepailitan maupun PKPU terhadap Perusahaan Go Public. Kelemahan ini menjadi tolok ukur selanjutnya dalam penelitian ini untuk melangkah dalam menyusun analisis lanjutan terkait dengan apa yang dapat dilakukan untuk dapat memaksimalkan pencapaian perdamaian yang berisi restrukturisasi utang tersebut. Sebagaimana juga telah disampaikan, bahwa pentingnya pencapaian perdamaian dalam proses kepailitan maupun PKPU dalam rangka memberikan perlindungan bagi investor pemegang saham publik, karena perdamaian merupakan jalan menurut Hukum Kepailitan Indonesia saat ini yang dapat memberikan peluang bagi investor pemegang saham publik untuk pulih dari kerugian atas dana yang telah disetorkan kepada Perusahaan Go Public. Dibandingkan dengan likuidasi yang merupakan hasil akhir dari kepailitan maupun PKPU oleh karena gagalnya proses negosiasi dengan kreditornya, yang kedua proses tersebut berakhir pada penjualan aset perusahaan, dan investor pemegang saham publik menurut analisis empiris di atas tidak pernah mendapatkan apapun.

\section{Simpulan}

Implementasi restrukturisasi utang terhadap Perusahaan Go Public berdasarkan Hukum Kepailitan Indonesia yang paling banyak digunakan di dalam praktiknya adalah penjadwalan kembali pelunasan utang atau rescheduling. Selain itu, rescheduling juga dikombinasikan dengan debt to equity swap, hair cut, pengurangan dan penundaan jumlah bunga tertunggak, 
asset sales dan equity carve-outs serta penambahan utang baru. Restrukturisasi utang tersebut terdapat di dalam perdamaian, baik di dalam proses kepailitan maupun PKPU. Fakta empiris menyatakan bahwa perkara-perkara kepailitan yang terkait dengan Perusahaan Go Public, tidak ada satupun tercapai perdamaian, sedangkan dari sebagian besar perkara PKPU yang terkait dengan Perusahaan Go Public tercapai perdamaian. Model restrukturisasi utang yang digunakan terhadap pencapaian persetujuan perdamaian adalah rescheduling yang dikombinasi dengan beberapa model lain sebagaimana tersebut $\mathrm{di}$ atas, akan tetapi kreditor juga akan melihat analisis solvabilitas dari Perusahaan Go Public tersebut. Jika analisis solvabilitasnya positif, maka perusahaan tersebut terkategori going concern dan kreditor akan yakin untuk menyetujui usulan perdamaian yang disampaikan, dan begitu juga sebaliknya.

\section{DAFTAR PUSTAKA}

Amalia, C., Thaif, H., Nasution, B., \& Sunarmi. (2013). Analisis Yuridis Penyelesaian Pembiayaan Bermasalah Pada Bank Syariah (Studi pada PT. Bank Muamalat Indonesia, Tbk di Kota Medan). USU Law Journal, 1(1).

De Cruz, P. (2010). Perbandingan Sistem Hukum: Common Law, Civil Law dan Socialist Law. diterjemahkan oleh Narulita Yusron dari Comparative Law in a Changing World. Jakarta: Nusa Media.

Hadiwidjojo, K. . (2016). Metode dan Konsep Restrukturisasi Sebagai Pelaksanaan Asas Kelangsungan Usaha Dalam Penundaan Kewajiban Pembayaran Utang (PKPU) Terhadap Perusahaan Publik dan Non Publik. Jurnal Hukum \& Pasar Modal, 7(2).

Irianto, C. (2015). Penerapan Asas Kelangsungan Usaha Dalam Penyelesaian Perkara Kepailitan dan Penundaan Kewajiban Pembayaran Utang (PKPU). Jurnal Hukum Dan
Peradilan, 4(3).

John, K., \& Ofek, E. (1995). Asset Sales and Increase in Focus. Journal of Financial Economics, 37(1).

Kairupan, D. (2014). Kepemilikan dan Pengendalian Perusahaan Terbuka Oleh Pihak Asing: Suatu Analisa Yuridis dan Komparatif. Jurnal Hukum \& Pasar Modal, 5(7).

Ratnawati, T. E. (2009). Kajian Terhadap Proses Penyelesaian Perkara Kepailitan dan Penundaan Kewajiban Pembayaran Utang di Pengadilan Niaga Jakarta Pusat. Jurnal Dinamika Hukum, 9(2).

Respatia, W., \& Fidiana. (2010). Kebijakan Restrukturisasi Utang Melalui Debt To Equity Swap. Ekuitas, 14(1).

Sari, L. A., \& Hutagaol, Y. (2009). Debt to Equity Ratio, Degree of Operating Leverage Stock Beta and Stock Returns of Food and Beverages Companies on The Indonesian Stock Exchange. Journal of Applied Finance and Accounting, 2(1).

Schipper, K., \& Smith, A. (1986). A Comparison of Equity Carve-Outs and Seasoned Equity Offerings: Share Price Effects and Corporate Restructuring. Journal of Financial Economics, 15(12).

Sitompul, M. M. · (2009). Penyelesaian Sengketa Utang Piutang Perusahaan Dengan Perdamaian di Dalam atau Di Luar Proses Kepailitan (Studi Mengenai Lembaga Penundaan Kewajiban Pembayaran Utang). Medan: Universitas Sumatera Utara.

Sjahdeini, S. R. (2002). Hukum Kepailitan: Memahami Faillissementsverordening Juncto Undang-Undang No.4 Tahun 1998. Jakarta: Pustaka Utama Grafiti.

Widjaja, G. (2003). Tanggung Jawab Direksi Atas Kepailitan Perseroan. Jakarta: Raja Grafindo Persada. 